\title{
Rapid Scoping Review of Laparoscopic Surgery Guidelines During the COVID-19 Pandemic and Appraisal Using a Simple Quality Appraisal Tool "EMERGE"
}

\author{
Sanjay Kumar Yadav ${ }^{1} \cdot$ Vikesh Agrawal $^{2}$ (D) Pawan Agarwal $^{1} \cdot$ Dhananjaya Sharma $^{1}$
}

Received: 20 July 2020 / Accepted: 11 September 2020 / Published online: 17 September 2020

(C) Association of Surgeons of India 2020

\begin{abstract}
The theoretical danger of virus transmission during laparoscopic surgery (LS) via surgical smoke and laparoscopy gas has led to the formulation of many guidelines during the COVID-19 pandemic. This rapid scoping review of these guidelines was done to assess the quality of their evidence and appraise them for their impact on surgical services from the global south. A simple quality appraisal tool was constructed which can be used to evaluate rapidly emerging guidelines for evidence as well as for the needs of the global south. This rapid scoping review was conducted according to the Preferred Reporting Items for Systematic reviews and Meta-Analyses extension for Scoping Reviews protocol. Electronic databases were searched with predefined strategy and retrieved papers were screened according to relevant criteria. A simple objective tool to assess the quality of rapidly emerging guidelines including evidence, methodology, ease, resource optimization, geography, and the economy was constructed. Twenty studies met the inclusion criteria. None of the guidelines qualified to be evidence-based clinical practice guidelines as the level of evidence was uniformly rated "low". A newly constructed tool showed good validation, reliability, and internal consistency. This rapid scoping review found two major research gaps: lack of systematic review of evidence during their development and insufficient weightage of their impact on surgical services from the global south. These significant issues were addressed by constructing a simple and more representative tool for evaluating rapidly emerging guidelines which also gives the rightful importance of their impact on surgical services from the global south.
\end{abstract}

Keywords COVID-19 pandemic $\cdot$ Laparoscopic surgery $\cdot$ Risk of virus transmission $\cdot$ Evidence-based guideline $\cdot$ Rapid scoping review · Appraisal tool

Whether the paper is based on a previous communication to a society or meeting (with full details) - The EMERGE tool has been "mentioned," and Table 1 is quoted in a special letter to British Journal of Surgery as a correspondence and is accepted. Citation no 4 included.

Vikesh Agrawal

drvikeshagrawal@gmail.com

Sanjay Kumar Yadav

sky1508@gmail.com

Pawan Agarwal

drpawanagarwal@yahoo.com

Dhananjaya Sharma

dhanshar@gmail.com

1 Department of Surgery, Netaji Subhash Chandra Bose Government Medical College, Jabalpur 482002, India

2 Pediatric Surgery Division, Department of Surgery, Netaji Subhash Chandra Bose Government Medical College, Nagpur Road, Jabalpur 482002, India

\section{Introduction}

The ongoing COVID-19 pandemic has already claimed hundreds of thousands of lives. Uncertainty, risk of exposure, and a large number of healthcare professionals (HCP) getting infected have changed surgical practice to a great extent. The theoretical danger of virus transmission during laparoscopic surgery (LS) via surgical smoke and laparoscopy gas prompted several academic/national associations to issue laparoscopic surgery guidelines during the COVID-19 pandemic. Even a cursory glance at these "guidelines" reveals that these do not qualify as "guidelines" because they have not passed the stringent tests of the quality of evidence and methodology by systemic review for each recommendation and hence cannot be graded by conventional tools like GRADE and AGREE II $[1,2]$. Additionally, recommendations from these "guidelines" have not been evaluated in terms of their 
consequences on already resource-constrained surgical services in low and middle-income countries (LMICs) [3]. Given the importance of this subject, we recognized an overt need to evaluate these guidelines in the form of a rapid scoping review and to construct a simple quality appraisal tool which gives due weightage to their impact on surgical services from the global south and can be used to evaluate rapidly emerging guidelines.

\section{Methodology}

This rapid scoping review of guidelines on laparoscopic surgery during COVID-19 was conducted according to the PRISMA-ScR (Preferred Reporting Items for Systematic reviews and Meta-Analyses extension for Scoping Reviews) protocol and did not need prior registration.

Search Strategy The following databases were searched from January 2020 to 15 th June 2020 for relevant studies: Medline, Embase, Global Health, Scopus, Web of Science Core Collection, WHO, Global Index Medicus, and Google Scholar. The search strategy included terms related to clinical practice guidelines and its synonyms ("clinical pathway", "clinical protocol", "consensus", "consensus development conference", "critical pathways", "guidelines", "practice guidelines", "health planning guidelines", "guideline", "practice guideline", "position statement", "policy statement", "practice parameter", "best practice", "standards", "recommendations") and coronavirus diseases and its synonyms ("SARS-cov 2", "covid 19", "coronavirus", "novel coronavirus", "coronavirus covid-19"). Apart from scholarly/published material, hand-searching of key international surgical associations, minimal access surgery associations and laparoscopic and endoscopic surgery associations, and grey literature search was also performed.

The inclusion criterion was that the guidelines on laparoscopic surgery must have been produced by a national/ international academic association/organization, in English literature. Exclusion criteria were guidelines exclusively concerned with anaesthesia procedure or open surgery; regional/ hospital/government guidelines; non-peer-reviewed guidelines; commentaries, reviews, viewpoints, opinions, or recommendations from individual author or group of authors or institutes.

Two reviewers (SKY and VA) reviewed the potential abstracts and, if required, full texts of the search material to select the studies that appeared to be a "best fit" with stated objectives. Full articles of selected studies were reviewed in detail, and resolution of any disagreements was done in consultation with third and fourth authors (PA and DS).

\section{Data Synthesis}

An all-inclusive list of relevant geographical, methodological, and surgical evaluation of evidence parameters was made after a preliminary review of included guidelines. Then, these parameters were looked for in every included guideline and were finally tabulated in a standardized Microsoft Excel Version 16 form. The result was assessed for each of the criteria and evaluated as recommended/not recommended/not available. Quality of evidence was graded according to GRADE guidelines: which grades them as very low/low/moderate/high [1].

\section{Construction of a New Simple Quality Appraisal Tool}

A simple objective framework to assess the quality of rapidly emerging guidelines-EMERGE (Evidence, Methodology, Ease, Resource, Geography \& Economy) —was constructed and utilized for appraisal [4]. In addition to evidence and methodology, it included 4 other domains: ease of understanding, optimization with available resources, the inclusion of input for different geographical areas, and economic implications with each domain having two rating items (Table 1). Items included in the domains had item-correlation value $\geq$ $0.3(0.73,0.75,0.66,0.74,0.30$, and 0.48 for E, M, E, R, G, and $\mathrm{E}$, respectively). Countries were graded as LMIC according to WHO definition.

Quality Appraisal Two independent reviewers (VA and PA) appraised each eligible guideline by using the EMERGE tool, and inter-rater variability was measured by intra-class correlation coefficient (ICC). The score was completed by assessors on a seven-point Likert scale ( $1=$ strongly disagree, $7=$ strongly agree). Total domain scores are scaled to a percentage of the maximum score in each domain; $100 \%$ is achieved if each reviewer scores 7 for both the items in a domain. The domain would score $0 \%$ if each reviewer scored 1 (the minimum value) for both the items in the domain.

Construct Validity of Tool EMERGE validation was done by circulating the highest-rated guideline on EMERGE in a PDF format to 50 responders, across the country, having more than 10 years of experience in laparoscopic surgery. Another document explaining the items and basics of EMERGE score was circulated for their understanding and were asked to fill a Google form (Likert scale on 12 items). Using statistical software, the responses were collated and the reliability and internal consistency of the tool were assessed using Cronbach's coefficient $(\mathrm{Ca}>0.7$, reliable) and inter-rater reliability was assessed using the intra-class correlation coefficient. Statistical analysis was done using IBM SPSS Statistics for Windows, version 21 (IBM Corp, Armonk, NY, USA). 
Table 1 EMERGE tool [4] for evaluation of quality of rapidly emerging recommendations during a pandemic

\begin{tabular}{|c|c|c|}
\hline Domain category & Item tool & $\begin{array}{l}\text { Total points (minimum- } \\
\text { maximum) }\end{array}$ \\
\hline \multirow[t]{2}{*}{ Evidence support } & 1. High class of evidence utilized & \multirow[t]{2}{*}{$2-14$} \\
\hline & 2. High level of evidence utilized & \\
\hline \multirow{2}{*}{$\begin{array}{c}\text { Methodology of } \\
\text { development }\end{array}$} & 1. Clearly defined methodology of development & \multirow[t]{2}{*}{$2-14$} \\
\hline & 2. Supported by evidence-based guidelines & \\
\hline \multirow[t]{2}{*}{ Easy understanding } & 1. Clarity available in recommendations & \multirow[t]{2}{*}{$2-14$} \\
\hline & 2. Point-wise conclusions available & \\
\hline \multirow{2}{*}{$\begin{array}{l}\text { Resource } \\
\text { optimization }\end{array}$} & 1. Implementable without procuring of new resources & \multirow[t]{2}{*}{$2-14$} \\
\hline & $\begin{array}{l}\text { 2. Utilization of existing resources and indigenous } \\
\text { low-cost alternatives }\end{array}$ & \\
\hline \multirow[t]{2}{*}{$\begin{array}{l}\text { Geographical } \\
\text { inclusion }\end{array}$} & $\begin{array}{l}\text { 1. Inclusion of opinion from different parts of world as } \\
\text { authors/contributor }\end{array}$ & \multirow[t]{2}{*}{$2-14$} \\
\hline & $\begin{array}{l}\text { 2. Inclusion of supporting evidence from different parts } \\
\text { of the world }\end{array}$ & \\
\hline \multirow{2}{*}{$\begin{array}{l}\text { Economic } \\
\text { implications }\end{array}$} & 1. Economic consideration included & \multirow[t]{2}{*}{$2-14$} \\
\hline & $\begin{array}{l}\text { 2. Minimum economic impact of adopting } \\
\text { recommendations. }\end{array}$ & \\
\hline
\end{tabular}

Maximum possible score for a domain $=7$ (strongly agree) $\times 2$ (items) $\times 2$ (appraisers) $=28$

Minimum possible score $=1($ strongly disagree $) \times 2($ items $) 2($ appraisers $)=4$

Domain score $=\frac{\text { Obtained score-minimum possible score }(4)}{\text { Maximum possible score }(28) \text {-minimum possible score }(4)} \times 100$

\section{Result}

The initial search yielded a total of 4098 studies, out of which 5 were found to be duplicate. A total of 3903 studies were excluded as they did not fulfil the inclusion criteria. The remaining 190 studies were screened; 170 were found to be recommendations from a group of authors, not national associations, and were excluded. The remaining 20 guidelines on laparoscopic surgery during the COVID-19 matching with predefined criteria were evaluated in this rapid scoping review (Fig. 1).

A summary of all guidelines with the origin of their country, academic association, type of study, type of evidence, and recommendations based on various surgical/technical parameters are shown in Table 2 [5-24].

In general, guidelines were embedded within a document that primarily focused on prevention of COVID-19 spread to HCPs, and recommendations provided by them were mostly non-specific covering a narrow range of items (Table 3 ).

A maximum number of guidelines originated from individual national associations (13/20), followed by regional societies $(5 / 20)$ and international societies (2/20). Globally, only $4 / 20$ guidelines were published by national associations from LMICs.

None of the guidelines qualified to be evidence-based clinical practice guidelines in terms of the level of evidence and the methodology adopted for the development of guidelines. The level of evidence was uniformly rated "low", as assessed by GRADE guidelines. [1] Half (11/20) of them were expert opinions, and a half (9/20) were consensus statements and therefore lacked a clear evidence base (Table 2).

All guidelines unequivocally recommended avoiding routine laparoscopic surgery, and some recommended avoiding emergency laparoscopic surgery and suggested a preference for open surgery (Tables 2 and 3 ).

Emphasis differed amongst guidelines, but most common recommendations $(\geq 70 \%)$ were on negative-pressure operating rooms, preoperative testing, use of personal protection equipment (PPE), reduction in hospital staff, low pneumoperitoneum pressure, and low flow rate during laparoscopy, minimizing energy device usage, use of smoke evacuator, and use of filtration system before trocar's removal. Few suggested avoiding high aerosol-generating procedures, avoiding surgical drains, avoiding frequent suction during surgery, and not using water seal for suction; however, most others were silent on these issues (Table 3). The safety of using the Veress method over open trocar access and safety of using a mesh was mentioned by only one guideline. There was no mention of advice on the selection of cases, induction of anaesthesia in a separate room, hand-assisted laparoscopic surgery, and provisions for simultaneous training and teaching (Tables 2 and $3)$. 


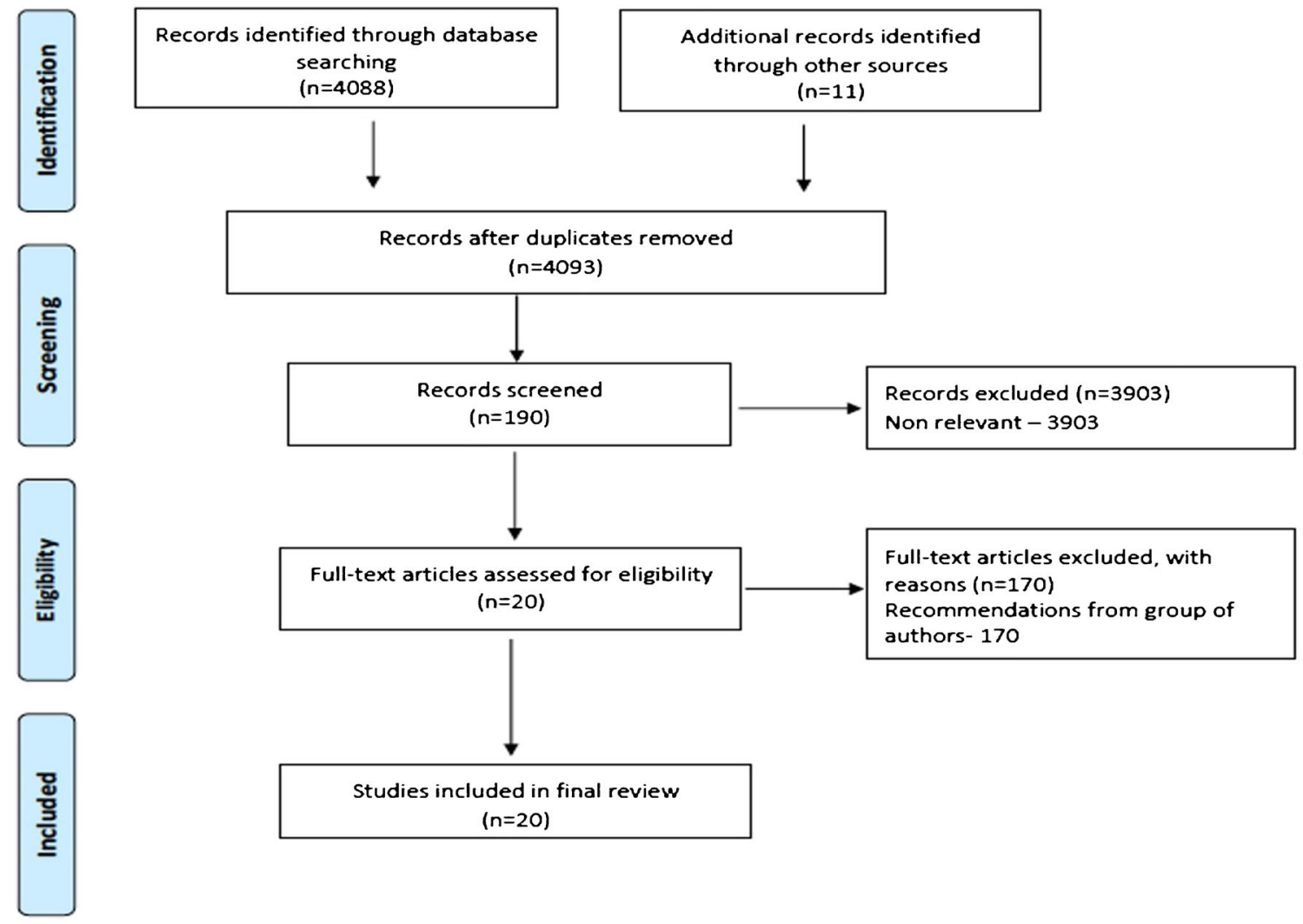

Fig. 1 Flow chart summarizing the results of the screening process and selection of studies as per the PRISMA guideline

Recommendations involving economic implications included the use of PPE (90\%), preoperative testing (80\%), use of negative pressure OR (70\%), use of commercial smoke evacuator (65\%), disposable trocar (55\%), dedicated COVID operating room (40\%), and preoperative CT chest in all patients $(10 \%)$. Many guidelines did not recommend any type of smoke filter while only one recommended using the indigenous low-cost filters to reduce cost (Table 3).

On appraisal of EMERGE by two independent reviewers (VA and PA), the ICCs were $0.78,0.83,0.76,0.84,0.47$, and 0.64 for E, M, E, R, G, and E, respectively $(<0.5$ - poor reliability, 0.5 to 0.75 - moderate reliability, 0.75 to $0.9-$ good reliability). The EMERGE appraisal of included guidelines revealed poor overall rating with a mean of $38.24 \%$ (range: $27.75-49.30 \%)$. Similarly, mean scores for the evidence $(30.39 \%)$, methodology $(40.41 \%)$, ease $(40.41 \%)$, resource $(32.07 \%)$, geography $(52.07 \%)$, and economy (24.97\%) domains were very modest. The Society of American Gastrointestinal and Endoscopic Surgeons \& European Association for Endoscopic Surgery guideline scored highest (49.30\%) followed by the Association of Surgeons of India (45.83\%), Endoscopic and Laparoscopic Surgeons of Asia (45.13\%), European Hernia Society $(45.12 \%)$, and Indian Inter-Society guidelines (44.43\%) [5, 7, 9, 12, 17] (Table 4).
Notwithstanding the Society of American Gastrointestinal and Endoscopic Surgeons \& European Association for Endoscopic Surgery guideline's highest overall mean score, it stood 2nd in resource optimization and 8th in economic implication domains [12]. Guidelines originating from LMICs stood poor on the evidence domain, but Indian InterSociety guidelines and Association of Surgeons of India guidelines from LMICs scored maximum in the resource optimization and economic implication domains [5, 17].

On validation of the EMERGE tool, the Cronbach's $\alpha$ coefficient was 0.95 (reliable) and $\mathrm{C} \alpha$ for each domain was more than 0.7 . The inter-rater reliability showed moderate agreement $(\mathrm{ICC}=0.571, p<0.001,95 \% \mathrm{CI}, 0.428<\mathrm{ICC}<$ 0.717).

\section{Discussion}

There are only three things that matter in Science: evidence, evidence, and evidence (to paraphrase Harold Samuel's famous quote about the value of property in relation to its location). Since widespread acceptance of Evidence-Based Medicine as the gold standard of clinical practice, the weight of each and every scientific publication must be measured on the balance of evidence. Clinical experience and evidence for 
Table 2 The status of the recommendations on laparoscopic surgery during COVID-19 vis à vis guidelines of the societies included in the study

\begin{tabular}{|c|c|c|c|c|c|c|c|c|c|c|c|}
\hline Criteria & IIS $^{5}$ & $\mathrm{AAGL}^{6}$ & $\mathrm{EHS}^{7}$ & $\mathrm{ALS}^{8}$ & ELSA $^{9}$ & $\begin{array}{l}\text { AGES } \\
\text { Nigeria }^{10}\end{array}$ & $\mathrm{SRS}^{11}$ & $\begin{array}{l}\text { SAGES } \\
\text { and } \\
\text { EAES }^{12}\end{array}$ & SERGS $^{13}$ & ALSGBI $^{14}$ & ISDE $^{15}$ \\
\hline Country & India & USA & Europe & Argentina & Asia & Nigeria & International & USA & Europe & UK & International \\
\hline $\begin{array}{l}\text { Type of } \\
\text { study }\end{array}$ & Consensus & Consensus & $\begin{array}{l}\text { Expert } \\
\text { opi- } \\
\text { nion }\end{array}$ & Guideline & Consensus & Guideline & Consensus & Guideline & Guideline & Consensus & Guideline \\
\hline $\begin{array}{l}\text { Class of } \\
\text { evidence }\end{array}$ & Low & Low & Low & Low & Low & Low & Low & Low & Low & Low & Low \\
\hline $\begin{array}{l}\text { Avoiding } \\
\quad \text { elective } \\
\text { laparoscopic } \\
\text { surgery }\end{array}$ & $\mathrm{Y}$ & Y & $\mathrm{Y}$ & $\mathrm{Y}$ & $\mathrm{Y}$ & $\mathrm{Y}$ & $\mathrm{Y}$ & $\mathrm{Y}$ & $\mathrm{Y}$ & $\mathrm{Y}$ & Y \\
\hline $\begin{array}{l}\text { Avoiding } \\
\text { emergency } \\
\text { laparoscopic } \\
\text { surgery }\end{array}$ & - & $\mathrm{N}$ & $\mathrm{N}$ & $\mathrm{N}$ & $\mathrm{N}$ & $\mathrm{N}$ & $\mathrm{N}$ & $\mathrm{N}$ & $\mathrm{N}$ & $\mathrm{N}$ & Y \\
\hline $\begin{array}{l}\text { Avoid high aerosol } \\
\text { surgery }\end{array}$ & - & - & - & - & - & - & - & - & - & - & - \\
\hline $\begin{array}{l}\text { Induction in separate } \\
\text { room }\end{array}$ & $\mathrm{N}$ & $\mathrm{N}$ & $\mathrm{N}$ & $\mathrm{N}$ & $\mathrm{N}$ & $\mathrm{N}$ & $\mathrm{N}$ & $\mathrm{N}$ & $\mathrm{N}$ & $\mathrm{N}$ & $\mathrm{N}$ \\
\hline $\begin{array}{l}\text { Negative- } \\
\text { pressure operative } \\
\text { room }\end{array}$ & Y & Y & $\mathrm{N}$ & $\mathrm{N}$ & $\mathrm{Y}$ & $\mathrm{N}$ & Y & Y & Y & $\mathrm{Y}$ & $\mathrm{Y}$ \\
\hline Preoperative testing & $\mathrm{Y}$ & Y & $\mathrm{Y}$ & $\mathrm{N}$ & Y & $\mathrm{Y}$ & Y & $\mathrm{Y}$ & $\mathrm{Y}$ & $\mathrm{Y}$ & $\mathrm{Y}$ \\
\hline $\begin{array}{l}\text { Preoperative } \\
\text { CT chest }\end{array}$ & - & $\mathrm{N}$ & $\mathrm{N}$ & $\mathrm{N}$ & $\mathrm{N}$ & $\mathrm{N}$ & $\mathrm{N}$ & $\mathrm{N}$ & Y & $\mathrm{N}$ & $\mathrm{N}$ \\
\hline Avoiding in positive & $\mathrm{Y}$ & - & $\mathrm{N}$ & $\mathrm{N}$ & $\mathrm{N}$ & $\mathrm{N}$ & $\mathrm{N}$ & $\mathrm{N}$ & $\mathrm{Y}$ & $\mathrm{N}$ & $\mathrm{N}$ \\
\hline COVID risk consent & $\mathrm{Y}$ & - & - & $\mathrm{N}$ & $\mathrm{Y}$ & - & - & $\mathrm{Y}$ & $\mathrm{Y}$ & - & - \\
\hline $\begin{array}{l}\text { Dedicated } \\
\text { COVID operative } \\
\text { room }\end{array}$ & $\mathrm{Y}$ & - & $\mathrm{N}$ & $\mathrm{Y}$ & Y & - & $\mathrm{N}$ & Y & $\mathrm{N}$ & - & $\mathrm{N}$ \\
\hline $\begin{array}{l}\text { Full personal } \\
\text { protective } \\
\text { equipment }\end{array}$ & $\mathrm{N}$ & Y & Y & $\mathrm{Y}$ in +ve & $\mathrm{Y}$ & Y & $\mathrm{Y}$ in +ve & Y & Y & Y & Y \\
\hline $\begin{array}{l}\text { Reduction of } \\
\text { hospital } \\
\text { staff }\end{array}$ & $\mathrm{Y}$ & $\mathrm{Y}$ & $\mathrm{N}$ & $\mathrm{Y}$ & $\mathrm{Y}$ & $\mathrm{Y}$ & $\mathrm{Y}$ & $\mathrm{Y}$ & $\mathrm{Y}$ & $\mathrm{Y}$ & Y \\
\hline $\begin{array}{l}\text { Trocar } \\
\text { insertion } \\
\text { site incision }\end{array}$ & $\mathrm{N}$ & $\mathrm{N}$ & $\mathrm{N}$ & $\mathrm{N}$ & Y & $\mathrm{N}$ & $\mathrm{N}$ & $\mathrm{N}$ & $\mathrm{N}$ & $\mathrm{Y}$ & - \\
\hline $\begin{array}{l}\text { Purse-string } \\
\text { suture/skin } \\
\text { blocking system }\end{array}$ & $\mathrm{N}$ & $\mathrm{N}$ & $\mathrm{N}$ & $\mathrm{N}$ & $\mathrm{Y}$ & $\mathrm{N}$ & $\mathrm{Y}$ & $\mathrm{N}$ & $\mathrm{N}$ & $\mathrm{N}$ & - \\
\hline $\begin{array}{l}\text { Disposable } \\
\text { trocar }\end{array}$ & $\mathrm{N}$ & $\mathrm{N}$ & $\mathrm{N}$ & $\mathrm{N}$ & Y & $\mathrm{N}$ & Y & Y & Y & $\mathrm{Y}$ & - \\
\hline $\begin{array}{l}\text { Low } \\
\text { insufflation } \\
\text { pressure } \\
\text { and flow } \\
\text { rate }\end{array}$ & - & $\mathrm{Y}$ & - & $\mathrm{Y}$ & $\mathrm{Y}$ & - & $\mathrm{Y}$ & Y & Y & $\mathrm{Y}$ & - \\
\hline $\begin{array}{l}\text { HEPA or } \\
\text { ULPA filter }\end{array}$ & - & ULPA & - & - & ULPA & - & ULPA & - & ULPA & ULPA & ULPA \\
\hline $\begin{array}{l}\text { Avoiding frequent } \\
\text { suction }\end{array}$ & - & $\mathrm{N}$ & - & - & - & - & - & - & - & - & - \\
\hline $\begin{array}{l}\text { Minimizing energy } \\
\text { devise } \\
\text { usage }\end{array}$ & $\mathrm{N}$ & $\mathrm{N}$ & $\mathrm{N}$ & $\mathrm{N}$ & $\mathrm{N}$ & $\mathrm{N}$ & - & $\mathrm{Y}$ & $\mathrm{Y}$ & $\mathrm{N}$ & - \\
\hline $\begin{array}{l}\text { Contained extraction } \\
\text { system }\end{array}$ & $\mathrm{Y}$ & Y & $\mathrm{Y}$ & - & $\mathrm{Y}$ & - & $\mathrm{Y}$ & $\mathrm{Y}$ & $\mathrm{Y}$ & $\mathrm{Y}$ & - \\
\hline $\begin{array}{l}\text { Filter use } \\
\text { before trocar's } \\
\text { removal }\end{array}$ & $\mathrm{Y}$ & $\mathrm{Y}$ & $\mathrm{Y}$ & $\mathrm{N}$ & $\mathrm{N}$ & $\mathrm{N}$ & $\mathrm{Y}$ & $\mathrm{Y}$ & $\mathrm{Y}$ & $\mathrm{N}$ & - \\
\hline $\begin{array}{l}\text { Avoiding surgical } \\
\text { drains }\end{array}$ & Y & - & - & - & Y & - & - & - & $\mathrm{Y}$ & - & - \\
\hline
\end{tabular}

\begin{tabular}{|c|c|c|c|c|c|c|c|c|}
\hline Criteria & $\operatorname{BCSLS}^{16}$ & $\mathrm{ASI}^{17}$ & BAUS $^{18}$ & $\mathrm{BSGE}^{19}$ & $\mathrm{ESGE}^{20}$ & ERUS $^{21}$ & $\begin{array}{l}\text { RCOG } \\
\text { BSGE }^{22}\end{array}$ & SASREG $^{23}$ \\
\hline
\end{tabular}

\begin{tabular}{|c|c|c|c|c|c|c|c|c|c|}
\hline Country & Brazil & India & UK & UK & Europe & Europe & UK & South Africa & ANZ \\
\hline $\begin{array}{l}\text { Type of } \\
\text { study }\end{array}$ & Guideline & Consensus & Guideline & Consensus & Guideline & Guideline & Consensus & Consensus & Guideline \\
\hline $\begin{array}{l}\text { Class of } \\
\text { evidence }\end{array}$ & Low & Low & Low & Low & Low & Low & Low & Low & Low \\
\hline $\begin{array}{l}\text { Avoiding } \\
\text { elective laparoscopic surgery }\end{array}$ & $\mathrm{Y}$ & $\mathrm{Y}$ & $\mathrm{Y}$ & $\mathrm{Y}$ & $\mathrm{Y}$ & $\mathrm{Y}$ & $\mathrm{Y}$ & $\mathrm{Y}$ & $\mathrm{Y}$ \\
\hline
\end{tabular}


Table 2 (continued)

\begin{tabular}{|c|c|c|c|c|c|c|c|c|c|}
\hline Avoiding emergency laparoscopic surgery & $\mathrm{N}$ & $\mathrm{N}$ & $\mathrm{N}$ & $\mathrm{Y}$ & $\mathrm{Y}$ & $\mathrm{Y}$ & Y & $\mathrm{N}$ & $\mathrm{N}$ \\
\hline $\begin{array}{l}\text { Avoid high aerosol } \\
\text { surgery }\end{array}$ & - & $\mathrm{Y}$ & $\mathrm{Y}$ & - & $\mathrm{Y}$ & $\mathrm{Y}$ & - & - & - \\
\hline $\begin{array}{l}\text { Induction in separate } \\
\text { room }\end{array}$ & $\mathrm{N}$ & $\mathrm{N}$ & $\mathrm{N}$ & $\mathrm{N}$ & $\mathrm{N}$ & $\mathrm{N}$ & $\mathrm{N}$ & $\mathrm{N}$ & $\mathrm{N}$ \\
\hline $\begin{array}{l}\text { Negative- } \\
\text { pressure operative } \\
\text { room }\end{array}$ & $\mathrm{Y}$ & $\mathrm{N}$ & $\mathrm{Y}$ & Y & Y & $\mathrm{N}$ & Y & $\mathrm{N}$ & Y \\
\hline Preoperative testing & Y & $\mathrm{Y}$ & $\mathrm{Y}$ & $\mathrm{Y}$ & - & $\mathrm{Y}$ & $\mathrm{Y}$ & $\mathrm{N}$ & - \\
\hline $\begin{array}{l}\text { Preoperative } \\
\text { CT chest }\end{array}$ & $\mathrm{N}$ & Y & $\mathrm{N}$ & $\mathrm{N}$ & - & $\mathrm{N}$ & $\mathrm{N}$ & $\mathrm{N}$ & - \\
\hline Avoiding in positive & $\mathrm{N}$ & $\mathrm{N}$ & $\mathrm{N}$ & $\mathrm{N}$ & $\mathrm{Y}$ & $\mathrm{Y}$ & $\mathrm{N}$ & $\mathrm{Y}$ & - \\
\hline COVID risk consent & - & $\mathrm{N}$ & - & $\mathrm{Y}$ & - & $\mathrm{Y}$ & Y & - & - \\
\hline $\begin{array}{l}\text { Dedicated } \\
\text { COVID operative } \\
\text { room }\end{array}$ & - & $\mathrm{Y}$ & Y & $\mathrm{N}$ & - & $\mathrm{Y}$ & $\mathrm{N}$ & - & Y \\
\hline Full personal protective equipment & $\mathrm{Y}$ & $\mathrm{Y}$ in $+\mathrm{ve}$ & Y & Y & Y & $\mathrm{Y}$ & $\mathrm{Y}$ & $\mathrm{Y}$ in $+\mathrm{ve}$ & Y \\
\hline $\begin{array}{l}\text { Reduction of hospital } \\
\text { staff }\end{array}$ & $\mathrm{Y}$ & $\mathrm{Y}$ & $\mathrm{Y}$ & Y & Y & Y & Y & - & Y \\
\hline $\begin{array}{l}\text { Trocar } \\
\text { insertion } \\
\text { site incision }\end{array}$ & Y & - & $\mathrm{N}$ & - & - & $\mathrm{N}$ & - & - & - \\
\hline Purse-string suture/skin blocking system & $\mathrm{N}$ & - & Y & - & - & $\mathrm{N}$ & - & - & - \\
\hline $\begin{array}{l}\text { Disposable } \\
\text { trocar }\end{array}$ & $\mathrm{Y}$ & $\mathrm{Y}$ & $\mathrm{Y}$ & - & - & $\mathrm{Y}$ & - & $\mathrm{Y}$ & $\mathrm{Y}$ \\
\hline $\begin{array}{l}\text { Low } \\
\text { insufflation pressure } \\
\text { and flow } \\
\text { rate }\end{array}$ & $\mathrm{Y}$ & - & $\mathrm{Y}$ & $\mathrm{Y}$ & - & $\mathrm{Y}$ & $\mathrm{Y}$ & $\mathrm{Y}$ & $\mathrm{Y}$ \\
\hline $\begin{array}{l}\text { HEPA or } \\
\text { ULPA filter }\end{array}$ & ULPA & ANY & ULPA & ULPA & - & ULPA & ULPA & HME & ULPA \\
\hline Avoiding frequent suction & - & Y & Y & - & - & $\mathrm{Y}$ & - & $\mathrm{Y}$ & - \\
\hline $\begin{array}{l}\text { Minimizing energy devise } \\
\text { usage }\end{array}$ & $\mathrm{N}$ & Y & $\mathrm{Y}$ & $\mathrm{Y}$ & Y & Y & Y & $\mathrm{Y}$ & Y \\
\hline Contained extraction system & Y & $\mathrm{Y}$ & Y & $\mathrm{Y}$ & Y & $\mathrm{Y}$ & $\mathrm{Y}$ & - & - \\
\hline $\begin{array}{l}\text { Filter use } \\
\text { before trocar's removal }\end{array}$ & $\mathrm{N}$ & Y & Y & - & - & $\mathrm{Y}$ & - & - & Y \\
\hline Avoiding surgical drains & - & - & - & - & - & $\mathrm{Y}$ & - & - & - \\
\hline
\end{tabular}

IIS Indian Inter Society, AAGL American Association of Gynecologic Laparoscopists, EHS European Hernia Society, ALS Argentine laparoscopic society, ELSA Endoscopic and Laparoscopic Surgeons of Asia, AGES Association of Gynecological Endoscopy Surgeons of Nigeria, SRS Society of Robotic Surgery, SAGES \& EAES Society of American Gastrointestinal and Endoscopic Surgeons (SAGES) and The European Association for Endoscopic Surgeons (EAES), SERGS Society of European Robotic Gynaecological Surgery, ALSGBI Association of Laparoscopic Surgeons of Great Britain and Ireland, ISDE International Society for Diseases of the Esophagus, BCSLS Brazilian College of Surgeons for laparoscopic surgery, ASI Association of Surgeons of India, BAUS British Association of Urological Surgeons, BSGE British Society for Gynaecological Endoscopy, ESGE European Society for Gynaecological Endoscopy, ERUS EAU Robotic Urology Section, RCOG Royal College of Obstetricians and Gynaecologists, SASREG- Southern African Society of Reproductive Medicine and Gynaecological Endoscopy, USANZ Urological Society of Australia and New Zealand, $C T$ computed tomography, HME heat and moisture exchangers, ULPA ultra-low particulate air

the ongoing COVID-19 pandemic are still evolving, making its analysis similar to the live coverage of an unfolding history. This makes a rapid scoping review an ideal approach to assess research conduct and identify knowledge gaps to provide knowledge synthesis in a timely manner, provided it is conducted with simplified but rigorous and transparent methods [25].

Evidence-based guidelines are important as they are looked up to and followed by all clinicians; these become even more relevant when faced with the challenge of a rampaging pandemic. A clinical decision can be well-informed and evidencebased only if the available guideline is the logical end-product of scientific evaluation, collation, and summarization of currently available evidence. To mitigate transmission of infection to healthcare professionals during laparoscopic surgery, many guidelines and recommendations emerged rapidly as the COVID-19 pandemic unfolded. The present rapid scoping review revealed that all laparoscopy guidelines for COVID19 were either expert opinions or consensus statements and did not qualify as evidence-based clinical practice guidelines in the absence of necessary evidence and methodology in their development (Table 2). This is symbolized by all laparoscopy procedures being labelled as high risk because an allpervading grave fear of infection to HCPs via surgical smoke and laparoscopy gas prompted the guidelines to err on the "side of safety" [26]. Studies have isolated bacterial/viral fragments in surgical smoke, but presently pathogen transmission via smoke and laparoscopic gas to HCPs has not been shown $[27,28]$.

In addition to a low level of evidence involved in the development of these rapidly emerging guidelines on laparoscopic surgery, the process of obtaining evidence and knowledge synthesis was lacking from these published guidelines. The guidelines for laparoscopy in high-risk groups like older 
Table 3 The distribution of the recommendations on laparoscopic surgery during COVID-19 in the included studies

\begin{tabular}{|c|c|c|c|}
\hline Criteria & Recommended & $\begin{array}{l}\text { Not } \\
\text { recommended }\end{array}$ & $\begin{array}{l}\text { Not } \\
\text { Mentioned }\end{array}$ \\
\hline $\begin{array}{l}\text { Age and co-morbidity consideration in } \\
\text { selection }\end{array}$ & 0 & 0 & $20(100 \%)$ \\
\hline Avoiding elective laparoscopic surgery & $20(100 \%)$ & 0 & 0 \\
\hline $\begin{array}{l}\text { Avoiding emergency laparoscopic } \\
\text { surgery }\end{array}$ & $5(25 \%)$ & $14(70 \%)$ & $1(5 \%)$ \\
\hline Avoid high aerosol surgery & $4(20 \%)$ & 0 & $16(80 \%)$ \\
\hline Induction in separate room & 0 & $20(100 \%)$ & 0 \\
\hline Negative pressure OR & $14(70 \%)$ & $6(30 \%)$ & 0 \\
\hline Preoperative testing & $16(80 \%)$ & $2(10 \%)$ & $2(10 \%)$ \\
\hline Preoperative CT chest & $2(10 \%)$ & $15(75 \%)$ & $3(15 \%)$ \\
\hline Avoiding in positive patients & $5(25 \%)$ & $13(65 \%)$ & $2(10 \%)$ \\
\hline COVID risk consent & $7(35 \%)$ & $2(10 \%)$ & $11(55 \%)$ \\
\hline Dedicated COVID OR & $8(40 \%)$ & $6(30 \%)$ & $6(30 \%)$ \\
\hline Full personal protective equipment & $\begin{array}{l}\text { In all cases-15 }(75 \%) \\
\text { In positive cases-3 }(15 \%) \\
\text { N95 in negative, full in positive- } \\
\quad 1(5 \%)\end{array}$ & $1(5 \%)$ & 0 \\
\hline Reduction in hospital staff & $18(90 \%)$ & $1(5 \%)$ & $1(5 \%)$ \\
\hline Trocar insertion site incision & $3(15 \%)$ & $10(50 \%)$ & $7(35 \%)$ \\
\hline $\begin{array}{l}\text { Purse-string suture/skin blocking } \\
\text { system }\end{array}$ & 0 & $13(65 \%)$ & $7(35 \%)$ \\
\hline Disposable trocar & $11(55 \%)$ & $5(25 \%)$ & $4(20 \%)$ \\
\hline Veress trocar insertion & $1(5 \%)$ & 0 & $19(95 \%)$ \\
\hline $\begin{array}{l}\text { Low pneumoperitoneum pressure and } \\
\text { flow rate }\end{array}$ & $14(70 \%)$ & 0 & $6(30 \%)$ \\
\hline Smoke evacuator & HME-1 (5\%) & - & $6(30 \%)$ \\
\hline Water seal for suction & $\begin{array}{l}\text { ULPA-13 }(65 \%) \\
0\end{array}$ & $5(25 \%)$ & $15(75 \%)$ \\
\hline Avoiding frequent suction & $4(20 \%)$ & $1(5 \%)$ & $15(75 \%)$ \\
\hline Minimizing energy device usage & $10(50 \%)$ & $8(40 \%)$ & $2(10 \%)$ \\
\hline Contained extraction system & $15(75 \%)$ & 0 & $5(10 \%)$ \\
\hline Use of filter before trocar's removal & $10(50 \%)$ & $5(25 \%)$ & $5(25 \%)$ \\
\hline Avoiding surgical drains & $4(20 \%)$ & 0 & $16(80 \%)$ \\
\hline Use of prosthesis e.g. Mesh & $1(5 \%)$ & 0 & $19(95 \%)$ \\
\hline Hand assisted surgery & - & - & $20(100 \%)$ \\
\hline Simultaneous training and teaching & - & - & $20(100 \%)$ \\
\hline
\end{tabular}

OR operation room, $C T$ computed tomography, HME heat and moisture exchangers, ULPA ultra-low particulate air people and those with comorbidities are conspicuously missing, as is any guideline on laparoscopic surgery from the World Health Organization. Inclusivity is vital in a pandemic; however, only $20 \%$ of guidelines originated from resourcepoor countries suggesting a low representation (Table 2).

The speed and severity of this unprecedented COVID-19 pandemic are posing critical challenges to the resources of even high-income countries (HICs). The strain put on already resource-constrained surgical services in LMICs has been unparalleled and crippling [3, 29]. This coupled with exclusion of their needs in laparoscopic surgery guidelines amounts to epistemic injustice [30]. This is illustrated by exorbitant costs of negative pressure ORs and commercial smoke evacuators, which are beyond the reach of most standalone hospitals that form the backbone of surgical care in LMICs. It proves that bearing the economic costs of these guidelines, like so many other COVID-19 issues, is significantly more difficult for LMICs.

This rapid scoping review revealed that much-needed resource optimization and economic implications of recommendations were not considered by most guidelines. Other studies have also noted that clinical guidelines and 
Table 4 EMERGE appraisal of six domains for the included guidelines (arranged in order of highest to lowest overall score)

\begin{tabular}{|c|c|c|c|c|c|c|c|}
\hline Guideline & $\begin{array}{l}\text { Evidence } \\
\text { support }(\%)\end{array}$ & $\begin{array}{l}\text { Methodology of } \\
\text { development (\%) }\end{array}$ & $\begin{array}{l}\text { Easy } \\
\text { understanding } \\
(\%)\end{array}$ & $\begin{array}{l}\text { Resource } \\
\text { optimization (\%) }\end{array}$ & $\begin{array}{l}\text { Geographical } \\
\text { inclusion }(\%)\end{array}$ & $\begin{array}{l}\text { Economic } \\
\text { implications (\%) }\end{array}$ & Mean \\
\hline $\begin{array}{c}\text { SAGES \& } \\
\text { EAES }^{12}\end{array}$ & 41.66 & 62.5 & 66.66 & 33.33 & 66.66 & 25 & 49.301(Highest) \\
\hline $\mathrm{ASI}^{17}$ & 33.33 & 58.33 & 66.66 & 33.33 & 50 & 33.33 & 45.83 \\
\hline ELSA $^{9}$ & 41.66 & 50 & 62.5 & 33.33 & 50 & 33.33 & 45.13 \\
\hline $\mathrm{EHS}^{7}$ & 41.66 & 62.5 & 62.5 & 33.33 & 54.16 & 16.6 & 45.125 \\
\hline $\mathrm{IIS}^{5}$ & 20.8 & 50 & 58.33 & 41.66 & 54.16 & 41.66 & 44.435 \\
\hline $\mathrm{AAGL}^{6}$ & 29.1 & 58.33 & 66.66 & 33.33 & 50 & 25 & 43.736 \\
\hline $\mathrm{ISDE}^{15}$ & 33.33 & 41.66 & 50 & 33.33 & 66.66 & 25 & 41.663 \\
\hline $\mathrm{SRS}^{11}$ & 41.66 & 37.5 & 41.66 & 33.33 & 66.66 & 25 & 40.968 \\
\hline SERGS $^{13}$ & 41.66 & 33.33 & 50 & 33.33 & 66.66 & 25 & 40.968 \\
\hline ALSGBI $^{14}$ & 41.66 & 41.66 & 45.83 & 33.33 & 58.33 & 25 & 40.968 \\
\hline $\operatorname{BCSLS}^{16}$ & 33.33 & 41.66 & 33.33 & 33.33 & 58.33 & 25 & 37.496 \\
\hline $\mathrm{ESGE}^{20}$ & 33.33 & 33.33 & 41.66 & 33.33 & 50 & 25 & 36.108 \\
\hline $\mathrm{ALS}^{8}$ & 16.6 & 25 & 45.83 & 33.33 & 50 & 33.33 & 34.015 \\
\hline $\begin{array}{l}\text { AGES } \\
\text { Nigeria }^{10}\end{array}$ & 16.6 & 33.33 & 37.5 & 33.33 & 50 & 33.33 & 34.015 \\
\hline USANZ $^{24}$ & 33.33 & 33.33 & 37.5 & 33.33 & 41.66 & 16.6 & 32.625 \\
\hline ERUS $^{21}$ & 33.33 & 29.1 & 45.83 & 25 & 41.66 & 16.6 & 31.92 \\
\hline $\begin{array}{l}\text { RCOG } \\
\text { BSGE }^{22}\end{array}$ & 16.6 & 33.33 & 41.66 & 33.33 & 41.66 & 16.6 & 30.53 \\
\hline SASREG $^{23}$ & 16.6 & 25 & 45.83 & 33.33 & 41.66 & 16.6 & 29.836 \\
\hline BAUS $^{18}$ & 25 & 25 & 33.33 & 16.6 & 41.66 & 25 & 27.765 \\
\hline BSGE $^{19}$ & 16.6 & 33.33 & 33.33 & 25 & 41.66 & 16.6 & 27.753 (lowest) \\
\hline Mean & 30.392 & 40.411 & 48.33 & 32.077 & 52.079 & 24.979 & 38.240 \\
\hline
\end{tabular}

IIS Indian Inter Society, AAGL American Association of Gynecologic Laparoscopists, EHS European Hernia Society, ALS Argentine Laparoscopic Society, ELSA Endoscopic and Laparoscopic Surgeons of Asia, AGES Association of Gynecological Endoscopy Surgeons of Nigeria, SRS Society of Robotic Surgery, SAGES \& EAES Society of American Gastrointestinal and Endoscopic Surgeons (SAGES) and The European Association for Endoscopic Surgeons (EAES), SERGS Society of European Robotic Gynaecological Surgery, ALSGBI Association of Laparoscopic Surgeons of Great Britain and Ireland, ISDE International Society for Diseases of the Esophagus, BCSLS Brazilian College of Surgeons for laparoscopic surgery, ASI Association of Surgeons of India, BAUS British Association of Urological Surgeons, BSGE British Society for Gynaecological Endoscopy, ESGE European Society for Gynaecological Endoscopy, ERUS EAU Robotic Urology Section, RCOG Royal College of Obstetricians and Gynaecologists, SASREG- Southern African Society of Reproductive Medicine and Gynaecological Endoscopy, USANZ Urological Society of Australia and New Zealand

their appraisal tools rarely include domains like cost implication, barriers, and facilitators in their implementation, alternative solutions, and practice settings [31, 32]. Conventional appraisal tools like AGREE II, which mainly assess the quality of evidence and methodological rigor in the development of guidelines, have rigorous but very exhaustive checklists. This makes them impractical for the evaluation of rapidly emerging guidelines in a pandemic scenario [33, 34]. EMERGE was developed to address these research gaps and followed the key steps to the development of appraisal tools: content analysis, identifying domains and items, construction of rating/scoring, and validation $[31,35]$. EMERGE includes, apart from the level of evidence and methodological rigor, crucial and wider domains like the ease of applicability, resource optimization, geographical representation, and economic consideration which are equally relevant to face such challenges. Its additional advantage is that its simple structure allows quick appraisal of rapidly emerging guidelines (Table 1).

When appraised by EMERGE, a low evidence base and a poor methodological rigor of all guidelines were reconfirmed. Similarly, issues of resource optimization, geographical inclusion, and economic implications drew poor scores, even the guideline with the maximum score for quality of evidence scored poorly on this issue [12]. However, a couple of guidelines from LMICs scored maximum in these domains, demonstrating the weight of their input on such a crucial issue [5, 17]. The end of COVID-19 is nowhere in sight, and its impact on global health will be long-lasting. Therefore, the quality of such 
rapidly emerging recommendations needs to be assessed in terms of infrastructure, resource, workforce, and financial challenges apart from the level of evidence and methodology [3].

It could be argued that there is no need for a duplication scoping review or a new appraisal tool. However, it has been shown that adopting a different type of evidence synthesis, i.e. a purposeful rapid scoping review with different aims, cannot be called duplication and can lead to important information and useful quality control process [36]. When research, writing, and peer review are rushed, as it was in the early part of the COVID-19 pandemic, opinions and anecdotes were confused with evidence, resulting in "research waste" with many methodological weaknesses and damaging consequences [37, 38]. In such a rapidly evolving scenario, replication by a rapid scoping review can provide the necessary insight for the specific needs of decision-makers and vitally contribute to the progress of research [39]. Moreover, failure to conduct upto-date reviews of guidelines may result in substantial adverse consequences for patients, practitioners, and health services [40]. Similarly, rapid research needs a rapid appraisal of relevant parameters; hence, EMERGE, a simple and quick "guideline to assess guidelines", was constructed.

"Primum non nocere: First, Do no harm to the patient" have been the guiding words for physicians since time immemorial. The current pandemic prompted this principle to be expanded for the first time to include HCPs due to the risk of cross-infection [41]. This pressure and the urgent need for the prompt production of laparoscopic surgery guidelines may have led to a temporary suspension of fundamental scientific principles in conducting evidence synthesis [42]. However, better scrutiny of evidence has led to many recent publications that suggest laparoscopy is safe in the COVID-19 era, provided precautions are taken [43-45]. This change is likely to be reflected in newer versions of guidelines, as they have to be continuously developing, more so in a rapidly evolving epidemic.

The need for rapid scaling in every context has led to many frugal innovative responses from LMICs [46]. In the context of surgical services, these include the use of strong exhaust fans in ORs to create a temporary negative pressure room and use of indigenous low-cost heat and moisture exchanger (HME) smoke filters $[47,48]$. These low-cost ideas may not be ideal but have the potential to provide good enough healthcare in the best way possible under given constraints [49]. These frugal innovations are in sync with the resource, geographic, and economic domains of the EMERGE tool.

The term "global south" is increasingly being used for the "LMICs" and "developing countries" which were earlier rather insensitively called the "Third World countries". Economic constraints of these countries are well known, but many were progressing towards Sustainable Development Goals before being hit hard by the COVID-19 pandemic. Their fragile efforts are now at increased risk of falling behind [50].
However, their pride and ambitions remain intact and this newly developed simple tool and its acronym "EMERGE" coincide with the aspirations of these "Emerging Economies". Moreover, "social distancing" has become a current buzz word; greater inclusion of needs of LMICs in rapidly emerging guidelines and their appraising tools will avoid the impression of "social distancing" between the Global North and Global South [49]. This rapid scoping review pointing out the exclusion of needs of the global south and development of a simple appraisal tool which includes those is a small step in that direction.

\section{Conclusion}

This rapid scoping review of rapidly emerging laparoscopic surgery guidelines during COVID-19 found two major research gaps: lack of systematic review of the evidence (due to the urgency of situation and fear for the safety of HCPs) during their development and insufficient weightage of their impact on surgical services from the global south. Both these significant issues were addressed by constructing a simple, easy, and more representative appraisal tool for evaluating rapidly emerging guidelines which give the rightful importance of their impact on surgical services from the global south.

Data Availability Available.

\section{Compliance with Ethical Standards}

Conflict of Interest The authors declare that they have no conflict of interest.

Ethics Approval Ethical approval was obtained.

Consent to Participate Not applicable.

Consent for Publication Not applicable.

Code Availability Not applicable.

\section{References}

1. Guyatt GH, Oxman AD, Schünemann HJ, Tugwell P, Knottnerus A (2011) GRADE guidelines: a new series of articles in the Journal of Clinical Epidemiology. J Clin Epidemiol 64(4):380-382

2. Brouwers MC, Kho ME, Browman GP, Burgers JS, Cluzeau F, Feder G, Fervers B, Graham ID, Grimshaw J, Hanna SE, Littlejohns P, Makarski J, Zitzelsberger L, for the AGREE Next Steps Consortium (2010) AGREE II: Advancing guideline development, reporting and evaluation in health care. CMAJ 182(18): E839-E842. https://doi.org/10.1503/cmaj.090449

3. Mazingi D, Navarro S, Bobel MC, Dube A, Mbanje C, Lavy C (2020) Exploring the impact of COVID-19 on progress towards 
achieving global surgery goals [published online ahead of print, 2020 Jun 2]. World J Surg:1-7. https://doi.org/10.1007/s00268$020-05627-7$

4. Agrawal V, Yadav SK, Agarwal P, Sharma D (2020) 'EMERGE': Construction of a simple quality appraisal tool for rapid review of laparoscopic surgery guidelines during COVID-19 pandemic. Special Research Letter. Br J Surg in Press. https://doi.org/10. 1002/bjs.11783]

5. Srivastava A, Nasta AM, Pathania BS, Sundaram E, Jani KV, Manickavasagam K, Asuri K, Lal P, Goel RG, Chaudhari T, Bansal VK (2020) Surgical practice recommendations for minimal access surgeons during COVID 19 pandemic - Indian inter-society directives. J Minim Access Surg 16(3):195-200. https://doi.org/10. 4103/jmas.JMAS_93_20

6. COVID-19: Joint statement on minimally invasive gynecologic surgery. J Minim Invasive Gynecol. 2020 May 24:S15534650(20)30250-8. https://doi.org/10.1016/j.jmig.2020.05.018

7. Stabilini C, East B, Fortelny R, Gillion JF, Lorenz R, Montgomery A, Morales-Conde S, Muysoms F, Pawlak M, Reinpold W, Simons M, de Beaux AC (2020) Correction to: European Hernia Society (EHS) guidance for the management of adult patients with a hernia during the COVID 19 pandemic. Hernia. 23:1. https://doi.org/10. 1007/s10029-020-02223-5

8. Quaranta M, Dionisi H, Bonin M, Cano MLE (2020) The Argentine Society of Laparoscopic Surgery letter on COVID-19. J Minim Invasive Gynecol S1553-4650(20)30232-6. https://doi. org/10.1016/j.jmig.2020.05.001

9. Shabbir A, Menon RK, Somani J, So JBY, Ozman M, Chiu PWY, Lomanto D (2020) ELSA recommendations for minimally invasive surgery during a community spread pandemic: a centered approach in Asia from widespread to recovery phases. Surg Endosc 34:1-6. https://doi.org/10.1007/s00464-020-07618-0

10. Alabi OC, Okohue JE, Adewole AA, Ikechebelu JI (2020) Association of gynecological endoscopy surgeons of Nigeria (AGES) advisory on laparoscopic and hysteroscopic procedures during the COVID-19 pandemic. Niger J Clin Pract 23(5):747-749

11. Porter J, Blau E, Gharagozloo F, Martino M, Cerfolio R, Duvvuri U, et al (2020) Society of Robotic Surgery Review: recommendations regarding the risk of COVID-19 transmission during minimally invasive surgery. BJU Int https://doi.org/10.1111/bju.15105

12. Francis N, Dort J, Cho E, Feldman L, Keller D, Lim R, Mikami D, Phillips E, Spaniolas K, Tsuda S, Wasco K, Arulampalam T, Sheraz M, Morales S, Pietrabissa A, Asbun H, Pryor A (2020) SAGES and EAES recommendations for minimally invasive surgery during COVID-19 pandemic. Surg Endosc 34(6):2327-2331

13. Kimmig R, Verheijen RHM, Rudnicki M, for SERGS Council (2020) Robot assisted surgery during the COVID-19 pandemic, especially for gynecological cancer: a statement of the Society of European Robotic Gynaecological Surgery (SERGS). J Gynecol Oncol 31(3):e59. https://doi.org/10.3802/jgo.2020.31.e59

14. Laparoscopy in The Covid-19 Environment - ALSGBI Position Statement. ALSGBI. 2020 Available from: https://www.alsgbi. org/2020/04/22/laparoscopy-in-the-covid-19-environment-alsgbiposition-statement/. Accessed on 2020 Jun 20

15. COVID-19 Guidance Statement [Internet]. ISDE. Available from: https://isde.net/covid19-guidance. Accessed on 2020 Jun 20

16. Felippe RR, Laurentino LD, Sá BD (2020) Recommendations of the Brazilian College of Surgeons for laparoscopic surgery during the COVID-19 pandemic. Rev Col Bras Cir 47:e20202570. https:// doi.org/10.1590/0100-6991e-20202570 Available from: http:// www.scielo.br/scielo.php?script $=$ sci_arttext\&pid $=\mathrm{S} 0100$ $69912020000100604 \& \operatorname{lng}=\mathrm{en}$. Accessed on 2020 Jun 20

17. Somashekhar SP, Shivaram HV, Abhaham SJ, Dalvi AN, Kumar A, Gode D, Misra S, Jain SK, Prasad CRK, Pillarisetti RR (2020) ASI's consensus guidelines: $\mathrm{ABCs}$ of what to do and what not during the COVID-19 pandemic [published online ahead of print,
2020 Jun 9]. Indian J Surg:1-11. https://doi.org/10.1007/s12262020-02452-z

18. Caunet.org. 2020. [online] Available at: $<\mathrm{https} / / /$ caunet.org/wpcontent/uploads/2020/04/BAUS-Guidance-on-Laparoscopy-v1. pdf> Accessed 05 June 2020

19. Gynaecological laparoscopy in the time of Coronavirus. https:// www.bsge.org.uk/news/laparoscopy-in-the-time-of-coronavirus/ Accessed 05 June 2020

20. Esge.org. 2020. Available from: https://esge.org/wp content/ uploads/2020/03/Covid19StatementESGE.pdf. Accessed on 20 June 2020

21. EAU Robotic Urology Section (ERUS) guidelines during COVID19 emergency | Uroweb. Uroweb. 2020. Available from: https:// uroweb.org/eau-robotic-urology-section-erus-guidelines-duringcovid-19-emergency/. Accessed on 20 June 2020

22. Joint RCOG / BSGE Statement on gynaecological laparoscopic procedures and COVID-19 [Internet]. BSGE. 2020. Available from: https://www.bsge.org.uk/news/joint-rcog-bsge-statementon-gynaecological-laparoscopic-procedures-and-covid-19/. Accessed on 20 June 2020

23. Guidance for Endoscopic Surgery during COVID-19: 6 April 2020. SASREG. 2020. Available from: https://sasreg.co.za/guidance-forendoscopic-surgery-during-covid-19-6-april-2020/. Accessed on 20 June 2020

24. Case Deferral, Laparoscopy and virtual meetings during COVID19 pandemic. Usanz.org.au. 2020. Available from: https://usanz. org.au/publicassets/f251dec1-9b82-ea11-90fb-0050568796d8/Pol023-Guidelines\%2D\%2D-Laparoscopy-Case-Deferral-DuringCOVID\%2D\%2DFinal.pdf. Accessed on 20 June 2020

25. Munn Z, Peters MDJ, Stern C, Tufanaru C, McArthur E, Aromataris E (2018) Systematic review or scoping review? Guidance for authors when choosing between a systematic or scoping review approach. BMC Med Res Methodol 18:143. Published online 2018 Nov 19. https://doi.org/10.1186/s12874-018-0611-x

26. Agrawal V, Sharma D. Initial advice to avoid laparoscopic surgery due to fear of COVID-19 virus transmission: where was the evidence? Br J Surg 2020. doi: https://doi.org/10.1002/bjs.11860. Online ahead of print

27. Vourtzoumis P, Alkhamesi N, Elnahas A, Hawel JE, Schlachta C (2020) Operating during COVID-19: is there a risk of viral transmission from surgical smoke during surgery? Can J Surg 63(3): E299-E301. https://doi.org/10.1503/cjs.007020

28. Veziant J, Bourdel N, Slim K (2020) Risks of viral contamination in healthcare professionals during laparoscopy in the Covid-19 pandemic. J Visc Surg S1878-7886(20)30115-6. https://doi.org/10. 1016/j.jviscsurg.2020.04.010

29. Meara JG, Leather AJ, Hagander L, Alkire BC, Alonso N, Ameh EA et al (2015) Global Surgery 2030: evidence and solutions for achieving health, welfare, and economic development. Lancet. 386(9993):569-624

30. Fricker M (2007) Epistemic injustice: power and the ethics of knowing. Oxford University Press. https://doi.org/10.1093/acprof: oso/9780198237907.001.0001

31. Siering U, Eikermann M, Hausner E, Hoffmann-Eßer W, Neugebauer EA (2013) Appraisal tools for clinical practice guidelines: a systematic review. PLoS One 8(12):e82915

32. Flodgren G, Hall AM, Goulding L, Eccles MP, Grimshaw JM, Leng GC, Shepperd S (2016) Tools developed and disseminated by guideline producers to promote the uptake of their guidelines. Cochrane Database Syst Rev Issue 8. Art. No.: CD010669. https:// doi.org/10.1002/14651858.CD010669.pub2

33. Grimmer K, Dizon JM, Milanese S, King E, Beaton K, Thorpe O et al (2014) Efficient clinical evaluation of guideline quality: development and testing of a new tool. BMC Med Res Methodol 14:63. Published 2016 Apr 2. https://doi.org/10.1186/1471-2288-14-63 
34. Siebenhofer A, Semlitsch T, Herborn T, Siering U, Kopp U, Hartig $\mathrm{J}$ (2016) Validation and reliability of a guideline appraisal minichecklist for daily practice use. BMC Med Res Methodol 16:39. Published 2016 Apr 2. https://doi.org/10.1186/s12874-016-0139-x

35. Brouwers MC, Kerkvliet K, Spithoff K, AGREE Next Steps Consortium (2016) The AGREE Reporting Checklist: a tool to improve reporting of clinical practice guidelines. BMJ 352:i1152

36. Page MJ, Welch VA, Haddaway NR, Karunananthan S, Maxwell LJ, Tugwell P (2020) 'One more time': why replicating some syntheses of evidence relevant to COVID-19 makes sense. J Clin Epidemiol. https://doi.org/10.1016/j.jclinepi.2020.05.024

37. Glasziou PP, Sanders S, Hoffmann T. Waste in covid-19 research. BMJ 2020; 369 https://doi.org/10.1136/bmj.m1847 (Published 12 May 2020) Cite this as: BMJ 2020;369:m1847

38. Dagens A, Sigfrid L, Cai E, Lipworth S, Cheung V, Harris E et al (2020) Scope, quality, and inclusivity of clinical guidelines produced early in the covid-19 pandemic: rapid review. BMJ 369: m1936. Published 2020 May 26. https://doi.org/10.1136/bmj. m1936

39. Nosek BA, Errington TM (2020) What is replication? PLoS Biol 18(3):e3000691

40. Chalmers I, Dickersin K, Chalmers TC (1992) Getting to grips with Archie Cochrane's agenda. BMJ. 305:786-788

41. Cohen SL, Liu G, Abrao M, Smart N, Heniford T (2020) Perspectives on surgery in the time of COVID-19: safety first. J Minim Invasive Gynecol 27(4):792-793

42. Hajibandeh S, Hajibandeh S, Antoniou SA, Antoniou GA (2020; Available online 22 June 2020) COVID -19 pandemic and the quality of evidence synthesis. Br J Surg. https://doi.org/10.1002/ bjs. 11766

43. Morris SN, Fader AN, Milad MP, Dionisi HJ (2020) Understanding the "scope" of the problem: why laparoscopy is considered safe during the COVID-19 pandemic. J Minim Invasive Gynecol 27: 789-791. https://doi.org/10.1016/j.jmig.2020.04.002

44. Mowbray NG, Ansell J, Horwood J, Cornish J, Rizkallah P, Parker A, Wall P, Spinelli A, Torkington J (2020) Safe management of surgical smoke in the age of COVID-19. Br J Surg. https://doi.org/ 10.1002/bjs. 11679

45. de Leeuw RA, Burger NB, Ceccaroni M, Zhang J, Tuynman J, Mabrouk M et al (2020) COVID-19 and laparoscopic surgery, a scoping review of current literature and local expertise. JMIR Public Health Surveill. https://doi.org/10.2196/18928

46. Harris M, Bhatti Y, Buckley J, Sharma D (2020) Fast and frugal innovations in response to the COVID19 pandemic. Nat Med. https://doi.org/10.1038/s41591-020-0889-1

47. Chow TT, Kwan A, Lin Z, Bai W (2006) Conversion of operating theatre from positive to negative pressure environment. J Hosp Infect 64(4):371-378

48. Mintz Y, Arezzo A, Boni L, Chand M, Brodie R, Fingerhut A; and the Technology Committee of the European Association for Endoscopic Surgery (2020) A low cost, safe and effective method for smoke evacuation in laparoscopic surgery for suspected coronavirus patients. Ann Surg. https://doi.org/10.1097/SLA. 0000000000003965

49. Agarwal V, Sharma D (2020) Frugal solutions for operating room during COVID-19 pandemic. Br J Surg 107(9):e331-e332. https:// doi.org/10.1002/bjs.11783 Online ahead of print

50. Schwalbe N, Lehtimaki S, Gutiérrez JB (2020) COVID-19: rethinking risk. Lancet Glob Health S2214-109X(20)30276-X

Publisher's Note Springer Nature remains neutral with regard to jurisdictional claims in published maps and institutional affiliations. 